\title{
HUBUNGAN EFEKTIFITAS KOMUNIKASI INTERPERSONAL ANTARA DOSEN DAN MAHASISWA DENGAN PRESTASI AKADEMIK MAHASISWA PSIKOLOGI UNIVERSITAS SRIWIJAYA PALEMBANG
}

\author{
Marleni \\ STISIPOL Candradimuka Palembang \\ Email : marleni.oke@gmail.com
}

\begin{abstract}
This study aims to determine the relationship between the effectiveness of interpersonal communication between lecturers and students and student academic achievement. This research is based on the five aspects proposed by Kumar (2002). This study used 83 respondents, namely students of Psychology at Sriwijaya University, Jakarta. The measuring instrument used in this is the scale of the effectiveness of interpersonal communication and documentation of academic achievement in the form of a GPA. The results showed that there was a significant relationship between interpersonal communication and academic achievement with a correlation $(r)=0.883$ with a significance of 0.001 where is the Spearman correlation rule, namely $(r p>0)$. A good achievement result is not only due to the effectiveness of interpersonal communication but there are also other supporting factors, such as student motivation and good academic ability.
\end{abstract}

Keywords: Interpersonal Communication, Academic Achievement, Psychology Students

\begin{abstract}
ABSTRAK
Penelitian ini bertujuan untuk mengetahui hubungan efektifitas komunikasi interpersonal antara dosen dan mahasiswa dengan prestasi akademik mahasiswa. Penelitian ini didasarkan pada lima aspek yang dikemukakan oleh Kumar (2002). Penelitian ini menggunakan 59 responden yaitu mahasiswa Psikologi Universitas Sriwijaya Palembang. Alat ukur yang digunakan dalam adalah skala efektifitas komunikasi interpersonal dan dokumentasi prestasi akademik berupa nilai IPK. Hasil penelitian menunjukkan terdapat hubungan yang signifikan antara komunikasi interpersonal dengan prestasi akademik dengan korelasi $(r)=0,883$ dengan signifikansi 0,001 dimana kaidah korelasi spearmen yaitu (rs>0). Sebuah hasil prestasi yang baik bukan hanya karena adanya efektifitas komunikasi interpersonal tetapi ada juga faktor-faktor lain yang mendukung, seperti motivasi pada mahasiswa dan kemampuan akademik yang baik.
\end{abstract}

Kata Kunci : Komunikasi Interpersonal, Prestasi Akademik, Mahasiswa Psikologi

\section{PENDAHULUAN}

Manusia adalah makhluk sosial yang selalu berelasi dengan sesamanya. Relasi dalam artian apapun dilakukan untuk menyampaikan ataupun menerima informasi sertamemiliki tujuan dalam perilakunya. Salah satu hubungan atau relasi yang dilakukan oleh manusia adalah dengan melakukan komunikasi. Sifat manusia untuk menyampaikan keinginannya dan untuk mengetahui hasrat orang lain, merupakan awal keterampilan manusia

Berkomunikasi secara otomatis melalui lambang-lambang isyarat, kemudian disusul dengan kemampuan untuk memberi arti setiap lambang itu dalam bentuk bahasa verbal (Nurjaman dan Umam, 2012). Bungin (2006) mengatakan bahwa dalam komunikasi ada tiga unsur penting yang selalu hadir dalam setiap komunikasi, yaitu sumber informasi (receiver), saluran 
(media), dan penerima informasi (audience). Komunikasi tidak berlangsung dalam ruang hampa-sosial, melainkan dalam konteks atau situasi tertentu (Mulyana,2008). Komunikasi bisa terjadi di manapun, kapanpun, dan dengan siapapun serta dalam segala situasi, salah satu contohnya adalah komunikasi antara dosen dengan mahasiswa. Komunikasi tersebut dapat terjadi pada proses belajar mengajar, baik di dalam kelas maupun di luar kelas. Membahas mengenai masalah proses belajar mengajar di perguruan tinggi, hubungan antara dosen dengan mahasiswa dalam berkomunikasi sangat perlu. Apabila hubungan antar dosen dengan mahasiswa tidak harmonis, maka dapat menciptakan komunikasi yang tidak baik (Ernawati dan Tjalla, 2012). Tujuan komunikasi tidak akan tercapai apabila suatu komunikasi tidak berjalan secara efektif. Efektivitas komunikasi interpersonal tercapai, bila komunikan menginterpretasikan pesan yang diterima mempunyai makna yang sama dengan maksud pesan yang disampaikan oleh komunikatornya (Supratiknya, 1995 dalam Gunawati, dkk, 2006). Kumar (2002, dalam Wiryanto 2004) mengungkapkan ciri-ciri efektifitas komunikasi interpersonal, yaitu: keterbukaan, empati, dukungan, rasa positif dan kesetaraan. Komunikasi yang baikakan membuat arti tentang pentingnya hubungan individual.

Sebuah Hubungan komunikasi diharapkan dapat membantu mahasiswa dalam mencapai prestasi belajarnya. Seperti yang diungkapkan oleh Sardiman (dalam Ernawati dan Tjalla, 2012) bahwa hasil belajar yang optimal banyak dipengaruhi oleh berbagai komponen belajar mengajar, diantaranya adalah hubungan antar dosen dan mahasiswa. Prestasi belajar biasanya merupakan sebuah prestasi akademik yang diperoleh oleh individu yang sedang atau sudah melewati proses kegiatan belajar secara formal pada jenjang tertentu.
Sedangkan prestasi akademik menurut Sobur (dalam Chairiyati, 2012) adalah merupakan perubahan dalam kecakapan tingkah laku, ataupun kemampuan yang dapat bertambah selama beberapa waktu dan tidak disebabkan oleh proses pertumbuhan tetapi adanya situasi belajar. Adanya keterbukaan dalam komunikasi memudahkan komunikasi memahami maksud dari pesan yang disampaikan oleh komunikator dan dapat mempengaruhi komunikan untuk bersikap dan bertingkah laku sesuai dengan harapan komunikator (Gunawati, 2006).

Dorongan ini lah yang kemudian disebut sebagai motivasi dalam berkomunikasi. Menurut Hybels (2001) ada 6 hal yang menjadi motivasi yang menyebabkan terjadinya komunikasi interpersonal yaitu: Pleasure (kesenangan), Affection (kasih sayang), Inclusion (penyertaan), Escape (pelarian), Relaxation (relaksasi), dan Control (kontrol). Ernawati dan Tjalal (2012) mengungkapkan bahwa hubungan dosen dengan mahasiswa di dalam proses belajar mengajar merupakan faktor yang sangat penting dalam menciptakan suasana belajar yang menyenangkan sehingga mahasiswa ingin belajar dan dosen nyaman dalam mengajar. Oleh karena itu dalam penelitian ini, peneliti akan melihat hubungan antara efektifitas komunikasi interpersonal pada mahasiswa Psikologi angkatan 2011 Universitas Sriwijaya Palembang.

Berdasarkan uraian yang telah peneliti jelaskan di latar belakang, peneliti membuat identifikasi masalah dalam penelitian ini adalah "Hubungan Efektifitas Komunikasi Interpersonal Antara Dosen dan Mahasiswa dengan Prestasi Akademik Mahasiswa Psikologi Universitas Sriwijaya Palembang". Tujuan penelitian ini yaitu mengetahui ada atau tidaknya hubungan efektifitas komunikasi interpersonal antara dosen dan mahasiswa dengan prestasi 
akademik mahasiswa Psikologi Universitas Sriwijaya Palembang.

\section{HIPOTESIS}

Hipotesis untuk penelitian ini adalah sebagai berikut :

1. Ho : Tidak ada hubungan yang signifikan antara efektifitas komunikasi antara dosen dan mahasiswa dengan prestasi akademik mahasiswa Piskologi Universitas Sriwijaya Palembang.

2. Ha : Ada hubungan yang signifikan antara efektifitas komunikasi dosen dan mahasiswa dengan prestasi akademik mahasiswa Piskologi Universitas Sriwijaya Palembang

\section{METODE PENELITIAN}

1. Jenis Penelitian Pada penelitian ini, penulis menggunakan jenis penelitian eksplanatif dengan pendekatan kuantitatif. Dalam penelitian ini, peneliti akan meneliti apakah efektifitas komunikasi antara dosen dan mahasiswa dengan prestasi akademik mahasiswa Piskologi signifikan terhadap prestasi belajar para mahasiswa.

2. Populasi dan sampel Populasi pada penelitian ini adalah semua mahasiswa psikologi Universitas Sriwijaya Palembang tahun ajaran 2011/2012 yang berjumlah 59 orang. Sample yang diambil adalah semua yang termasuk populasi yaitu mahasiswa psikologi Universitas Sriwijaya Palembang yang berjumlah 59 orang.

3. Teknik Pengumpulan Data Data yang digunakan adalah data yang didapat peneliti dengan menggunakan kuesioner yang dibagikan kepada sample.

4. Uji Validitas dan Rehabilitas Uji validitas dalam penelitian ini adalah validitas isi (Content) dengan menggunakan teknik analisis Product Moment (Pearson's Correlation) dengan menggunakan bantuan SPSS For Windows versi 11.5.
Uji validitas dalam penelitian ini memakai signifikansi 5\% dengan jumlah responden (n) 59 orang yang berarti $\mathrm{df}=(\mathrm{n}-2)=57$. Pernyataan dikatakan valid jika nilai rhitung > 0,256 dan tidak valid jika rhitung 0,6 Hasil dari uji validitas yaitu nilai rhitung masing-masing nomer pernyataan dari kuesioner lebih besar dari nilai rtabel=0,256.

Sedangkan jika hasil nilai Alpha Cronbach dengan menggunakan bantuan SPSS For Windows versi 11.5. Pernyataan dalam kuesioner dikatakan reliabel apabila hasil nilai Alpha $>0,6$ sedangkan jika hasil nilai Alpha. Hasil dari uji reabilitas diperoleh angka koefisian reabilitas diatas 0,6240 yang berarti lulus uji reabilitas.

\section{Teknik Analisis Data}

Metode analisisnya adalah analisis Spearman's Rho Rank - Order Correlations). Rumus teknik statistik ini digunakan untuk mencari koefesien korelasi atau derajat kekuatan hubungan antara data ordinal/interval dan data ordinal lainnya. (Kriyantono, 2006 : 178).

\section{HASIL DAN PEMBAHASAN}

\section{Hasil Penelitian}

Dari data yang diperoleh, diolah menjadi data korelasi antara variabel efektifitas komunikasi antara dosen dan mahasiswa dengan prestasi akademik mahasiswa psikologi mengguankan teknik Spearman dan menghasilkan data sebagai berikut :

Tabel 1

Hasil korelasi efektifitas komunikasi dengan nilai prestasi akademik

\section{Correlations}

\begin{tabular}{|c|c|c|c|c|c|}
\hline $\begin{array}{c}\text { Keterbu } \\
\text { kaan }\end{array}$ & Empati & Dukungan & $\begin{array}{c}\text { Rasa } \\
\text { Positif }\end{array}$ & $\begin{array}{c}\text { Keset } \\
\text { araan }\end{array}$ & Nilai \\
\hline
\end{tabular}




\begin{tabular}{|r|r|r|r|r|r|}
\hline 1.000 & .230 & .337 & .291 & .180 & .375 \\
- & .080 & .009 & .025 & .172 & .003 \\
59 & 59 & 59 & 59 & 59 & 59 \\
\hline .230 & $\mathbf{1 . 0 0 0}$ & .501 & .521 & .429 & .838 \\
.080 & - & .000 & .000 & .001 & .000 \\
59 & 59 & 59 & 59 & 59 & 59 \\
\hline .337 & .501 & $\mathbf{1 . 0 0 0}$ & .422 & .291 & .703 \\
.009 & .000 & - & .001 & .025 & .000 \\
59 & 59 & 59 & 59 & 59 & 59 \\
\hline .291 & .521 & .422 & $\mathbf{1 . 0 0 0}$ & .488 & .621 \\
.025 & .000 & .001 & - & .000 & .000 \\
59 & 59 & 59 & 59 & 59 & 59 \\
\hline .180 & .429 & .291 & .488 & $\mathbf{1 . 0 0 0}$ & .514 \\
.172 & .001 & .025 & .000 & - & .000 \\
59 & 59 & 59 & 59 & 59 & 59 \\
\hline .375 & .838 & .703 & .621 & .514 & $\mathbf{1 . 0 0 0}$ \\
.003 & .000 & .000 & .000 & .000 & - \\
59 & 59 & 59 & 59 & 59 & 59 \\
\hline
\end{tabular}

**.Correlation is significant at the 0.01 level (2-tailed).

*.Correlation is significant at the 0.05 level (2-tailed).

Tabel diatas menunjukkan data tentang hubungan efektifitas komunikasi antarpribadi dengan nilai prestasi akademik yang keseluruhan menunjukkan terdapat hubungan yang signifikan pada level 0.01. Korelasi yang paling besar ditunjukkan oleh dimensi empati yaitu sebesar 0,838 .

Hasil penelitian diatas merupakan hasil tabulasi silang antara efektifitas komunikasi Keterbukaan Empati Dukungan Rasa Positif Kesetaraan Nilai Spearman's rho Keterbukaan Empati Dukungan Rasa Positif Kesetaraan Nilai **.Correlation is significant at the 0.01 level (2-tailed). *.Correlation is significant at the 0.05 level (2-tailed). 10 antara dosen dan mahasiswa dengan prestasi akademik mahasiswa psikolohi Universitas Sriwijaya Palembang.

Uji korelasi ini dibantu dengan menggunakan SPSS for windows versi 11.5. Hasil uji korelasi bivariat spearman diperoleh sebesar 0.883 seperti dibawah ini :

\section{Tabel 2}

Hubungan antara efektifitas komunikasi antara dosen dan mahasiswa Dengan prestasi akademik

\section{Correlations}

\begin{tabular}{|c|c|c|}
\hline & $\begin{array}{c}\text { Efektifitas } \\
\text { Komunikasi antara }\end{array}$ & Nilai \\
\hline
\end{tabular}

\begin{tabular}{|c|c|c|}
\hline & $\begin{array}{c}\text { dosen dan } \\
\text { mahasiswa }\end{array}$ & \\
\hline Spearmans's rho Efektifitas & $\mathbf{1 . 0 0 0}$ & $\mathbf{. 8 8 3}$ \\
komunikasi Correlation Coef & - & $\mathbf{. 0 0 0}$ \\
Antarpribadi Sig. (2-tailed) N & $\mathbf{5 9}$ & $\mathbf{5 9}$ \\
\hline Nilai Correlation Coef & $\mathbf{. 8 8 3}$ & $\mathbf{1 . 0 0 0}$ \\
& $\mathbf{. 0 0 0}$ & - \\
Sig. (2-tailed) N & $\mathbf{5 9}$ & $\mathbf{5 9}$ \\
\hline$*$ Correlation is significant at the 0.01 \\
level (2-tailed)
\end{tabular}

Berdasarkan skala Guilford, dengan hasil $r s=0.883$ dinyatakan bahwa terdapat hubungan yang signifikan. Dengan demikian, dapat diambil kesimpulan bahwa efektifitas komunikasi antara dosen dan mahasiswa memiliki hubungan yang signifikan dengan prestasi akademik mahasiswa psikologi.

\section{Pembahasan}

Beberapa responden memiliki keterbukaan, empati, dukungan, rasa positif dan kesetaraan yang tinggi, hal ini menjadikan komunikasi yang dijalin antara guru dan murid efektif. Hasil perhitungan menggunakan rumus korelasi Spearman antara efektifitas komunikasi antara dosen dan mahasiswa dengan prestasi akademik mahasiswa psikologi memakai bantuan SPSS for windows versi 11.5 diperoleh rs sebesar 0.883 . Sesuai dengan kaidah Spearman, yaitu rs $>$ 0, maka Ha (Hipotesis alternatif) yang menyatakan terdapat hubungan yang signifikan antara efektifitas komunikasi antara dosen dan mahasiswa dengan prestasi akademik mahasiswa psikologi Universitas Sriwijaya Palembang di terima.

Untuk mengetahui kuat lemahnya hubungan diantara variabel yang diteliti, terdapat skala $0,40 \quad-\quad 0,7$ untuk koefisiensi korelasi yang cukup berarti, sedangkan skala $0,71-0,90$ untuk koefisiensi korelasi yang kuat. Dengan rs sebesar 0,883 menunjukkan berada dalam skala 0,71 - 0,90 yang berarti koefisiensi korelasi yang kuat. Hubungan yang ada 
bersifat positif sehingga dapat disimpulakan bahwa semakin tinggi efektifitas komunikasi antara dosen dan mahasiswa maka semakin tinggi prestasi akademik mahasiswa psikologi.

\section{SIMPULAN DAN SARAN}

1. Kesimpulan

Berdasarkan keseluruhan hasil penelitian yang telah dilakukan oleh peneliti, sesuai dengan kaidah korelasi Spearmen menunjukkan diperoleh rs sebesar 0.883 pada level signifikansi 0.01. Sesuai dengan kaidah Spearman, yaitu rs > 0, maka Ha yang menyatakan terdapat hubungan yang signifikan antara efektifitas komunikasi antarpribadi guru dan murid dengan prestasi akademik murid program akselerasi SMA Negeri 3 surakarta diterima pada level 0.01.

Maka diperoleh kesimpulan yaitu efektifitas komunikasi antarpribadi mempunyai hubungan yang kuat dengan prestasi akademik. Hubungan yang terjadi bersifat positif yaitu semakin tinggi efektifitas komunikasi antarpribadi guru dengan murid maka semakin tinggi prestasi akademik.

2. Saran

Adanya berbagai kekurangan dan keterbatasan dalam pelaksanaan penelitian penulis terhadap penelitian ini, penulis ingin memberikan saran diantaranya:

a. Untuk melakukan aktivitas belajar mengajar perlu ditingkatkan komunikasi antarpribadi yang dijalin, hal ini tidak hanya sebagai faktor peningkatan nilai prestasi akademik murid, namun juga mampu meningkatkan prestasi non akademik murid yang mungkin murid belum pernah mengungkapkan bakatnya. Dengan adanya keterbukaan maka hal tersebut mampu membuat prestasi akademik maupun non akademik lebih tinggi.

b. Indikator empati dalam efektivitas komunikasi antarpribadi dapat lebih efektif digunakan pada mata pelajaran Matematika untuk mendukung perolehan nilai prestasi akademik murid yang kurang tinggi pada mata pelajaran ini.

c. Bagi penelitian selanjutnya, diharapkan dapat lebih menyempurnakan penelitian yang sekarang untuk mengganti variabel efektifitas komunikasi antarpribadi dengan variabel lain yang dapat mempengaruhi prestasi belajar murid.

\section{DAFTAR PUSTAKA}

Bungin, B. (2006). Sosiologi Komunikasi: Teori, Paradigma, Dan Diskursus Masyarakat Teknologi Komunikasi Di Masyarakat. Jakarta: Prenada Media Group

Chairiyati, L. (2012). Peran Prokastinasi Akademik, Self-Efficacy Akademik dan Konsep Diri Akademik Terhadap Prestasi Akademik. Jakarta

Ernawati \& Tjalla. (2012). Hubungan Komunikasi Interpersonal Antara Mahasiswa Dan Dosen Dengan Prestasi Akademik Mahasiswa Fakultas Psikologi Universitas Gunadarma, retrieved September 18, http://www.gunadarma.ac.id/library/ articles/graduate/psychology/2009/A rtikel_1 0503067.pdf

Gunawati, R., Hartati,S., Listiara, A. (2006). Hubungan Antara Efektivitas Komunikasi Mahasiswa-Dosen Pembimbing Utama Skripsi Dengan Stres Dalam Menyusun Skripsi Pada Mahasiswa Program Studi Psikologi Fakultas kedokteran Universitas Diponegoro: Jurnal Psikologi 
Universitas Diponegoro, Vol. 3 (2): 93- 115

Hybels, S., L, Richard., II, Weaver. (2001). Communicating Effectively. (6th ed.). New York: McGraw-Hill.

Mulyana, D. (2008) Ilmu Komunikasi Suatu Pengantar. Bandung: Rosdakarya Offset

Nurjaman, K \& Umam. (2012). Komunikasi Dan Publik Relation. Bandung: Pustaka Setia

Noor, J. (2011). Metodologi Penelitian Skripsi, Tesis, Disertasi \& Karya Ilmiah. Jakarta: Kencana Prenada Media Group

Wiryanto. (2004). Pengantar Ilmu Komunikasi. Jakarta: Grasindo Anggota Ikapi

Chairiyati. 2012. Hubungan Efektifitas Komunikasi Interpersonal Antara Dosen dan Mahasiswa dengan Prestasi akademik Mahasiswa Psikologi Universitas Bina Nusantara. Skripsi. Universitas Bina Nusantara. Malang : 2013.
Effendy, Onong Uchjana. 2001. Ilmu Komunikasi Teori dan Praktik. Bandung : PT Remaja Rosdakarya.

Gunawati, R., Hartati dan S., Listiara, A. 2006. Hubungan Antara Efektifitas Komunikasi Mahasiswa Dosen Pembimbing Utama Skripsi dengan Stres dalam Menyusun Skripsi Pada Mahasiswa Program Studi Psikologi Fakultas Kedokteran UNDIP. Jurnal Psikologi Universitas Diponegoro vol.3 no.2. Yogyakarta : 2006.

Kriyantono, Rachmat. 2006. Teknik Praktis Riset Komunikasi. Jakarta: PT Kencana Prenada Group.

Suciati. 2015. Komunikasi Interpersonal : Sebuah Tinjauan Psikologis dan Perspektif Islam. Yogyakarta : Buku Litera. 